\title{
Pengaruh Jantung Pisang (Musa Paradisiaca L.) terhadap Produksi ASI
}

\author{
Sri Wulan ${ }^{1 *}$, Desri Meriahta Br Girsang ${ }^{2}$ \\ 'Fakultas Kebidanan, Institut Kesehatan Medistra Lubuk Pakam, Lubuk Pakam, 20512, Indonesia \\ ${ }^{2}$ Fakultas Kesehatan Masyarakat, Institut Kesehatan Medistra Lubuk Pakam, Lubuk Pakam, 20512, Indonesia \\ ${ }^{1}$ wulan194@gmail.com*; ${ }^{2}$ desrimehrita@gmail.com; \\ * corresponding author
}

\section{ARTICLE INFO}

Keywords

Jantung Pisang

Produksi ASI

Ibu Menyusui

\begin{abstract}
The World Health Organization recommends that every baby be exclusive breastfeeding until the baby reaches the first 6 months of age, because breastfeeding is an important part of the baby's diet until the baby is six month to two years old and the mother is the main source of milk production so that the mother's nutrition must be fulfilled. This study aims to determine the effect of banana blossoms on milk production. The method used the Quasi Experiment with a Pretest-Posttest With Control Group design. The population in this study were all mothers breastfeeding infants aged 0-6 months in Sidodadi Ramunia Village, Beringin District Sampling using Probability Sampling technique by determining the inclusion and exclusion criteria of 20 breastfeeding mothers. Data analysis using frequency distribution data and Independent Sample Test with a confidence level of $95 \%$. The results showed that the smoothness of breastfeeding in the intervention group and the control group, there was a difference in value of 149.0 with a $p$ value of 0.01 , which means that there was a significant difference in the two groups and seen from the infant indicator, the difference in the average value of urine elimination for infants in the intervention and control groups was 24.00 with $\mathrm{p} 0.001$, the difference in the average value of the frequency of baby defecation is 0.900 with a $p$ value of 0.027 and seen from the number of hours of sleep for babies there is a difference in the value of 3.100 with a $p$ value of 0.025 which means that there is an effect of giving banana blossoms stew on milk production, both seen from the smoothness of the mother's milk or from the baby indicator. It is recommended for nursing mothers to routinely consume banana blossoms because banana blossoms are proven to increase milk production.
\end{abstract}

\section{Pendahuluan}

Pemberian Air Susu Ibu (ASI) secara eksklusif merupakan salah satu bentuk upaya yang dapat dilakukan untuk meningkatkan status gizi anak dalam 1000 Hari Pertama Kelahiran (HPK). Hal ini didukung dengan kebijakan pemerintah tentang pemberian ASI eksklusif di wilayah Indonesia yang sudah ditetapkan mulai tahun 2004 yang lalu, melalui Kepmenkes RI Nomor 450/Menkes/SK/IV/2004 dan didukung oleh Peraturan Pemerintah Nomor 33 Tahun 2012. Akan tetapi, aturan pemerintah terkait ASI eksklusif tidak dibarengi dengan tingginya capaian pemberian ASI eksklusif.di Indonesia sendiri sudah menjadi budaya namun praktik pemberian ASI masih jauh dari yang diharapkan oleh pemerintah. Menurut Survei Demografi Kesehatan Indonesia (SDKI) 2015 hanya terdapat $10 \%$ bayi yang mendapat ASI segera setelah lahir, 73\% yang mendapat ASI sampai usia 2 bulan, 53\% mendapat ASI sampai usia 2 ke 3 bulan, 20\% mencapai 4 bulan dan hanya $49 \%$ yang menysusu eksludif hingga usia bayi 6 bulan [1].

Organisasi Kesehatan Dunia juga merekomendasikan agar setiap bayi dapat disusui secara eksklusifsampai usia bayi mencapai 6 bulan pertama, karena menyusui merupakan bagian penting 
dari makanan bayi sampai bayi berumur enam hingga dua tahun[2]. Banyak manfaat kesehatan yang berkaitan dengan menyusui karena ASI memiliki komponen bioaktif yang ada di dalamnya serta memiliki efek biologis yang dipastikan berkaitan secara langsungdari frekuensi dan durasi menyusui[3].

ASI juga mampu memenuhi kebutuhan nutrisi tubuh bayi selama usia 6 bulan, tetapi hanya sedikit ibu yang dapat memberikan ASI secara eksklusif selama 6 bulan pertama, hal ini dikarenakan banyak faktor, diantaranya karena kurangnya pengetahuan dan informasi ibu tentang manfaat ASI secara Eksklusif, Pendidikan ibu yang rendah, dan masih banyak ibu yang beranggapan bahwa menyusui bayi kerap dihubungkan dengan keindahan payudara karena menganggap bahwa bayi yang menyusu ASI secara langsung dapat membuat payudara ibu menjadi kendor [4]. dr. Roesli, seorang spesialis anak mengadakan seminar ASI mengungkapkan bahwa sesungguhnya bukan dikarenakan menyusui yang merubah bentuk payudara ibu, tetapi karena proses kehamilan yang menyebabkan perubahan tersebut terjadi secara fisiologis [5].

ASI memiliki kandungan laktosa yang sangat tinggi dan memilikikandungan lemak yang akanmeningkat selama ibu menyusui. Meningkatnya angka menyusui akan meningkatkan kesehatan ibu dan anak, tetapi banyak hambatan untuk dapatbertahan menyusui hal ini juga disebabkan karena Produksi ASI ibu yang kurang sehingga ASI tidak dapat keluar dengan lancar dan kebutuhan bayi menjadi tidak tercukupi.Banyak cara untuk menilai produksi ASI salah satunya dapat dilihat dari indikator bayi misalnya dengan cara mengukur urin bayi selama 24 jam, frekuensi bayi buang air kecil sebanyak 6-8 kali selama 24 jam, warna urin kuning jernih, frekuensi buang air besar 3-4 hari sekali, jumlah jam tidur bayi 16 - 18 jam per/hari, jika ASI cukup setelah menyusu maka bayi tertidur atau tenang selama 2- 3 jam sekali [6].

Dampak dari ASI yang tidak lancar membuat ibu berpikir bahwa bayi mereka tidak akan mendapat cukup nutrisi sehingga ibu langsung mengambil keputusan untuk berhenti menyusui dan menggantinya dengan susu formula, sementara bayi yang tidak diberi ASI secara efektif, tetapi diberi susu formula akan lebih berisiko alergi terhadap makanan atau paparan udara, mudah terserang diare, menderita asma, gampang obesitas, dapat menderita diabetes, terjadi gangguan pencernaan, gangguan pada gigi dan maloklusi, dapat menderita anemia defisiensi besi, hipertensi bahkan sampai komplikasi pada bagian jantung. Berdasarkan hasil penelitian para ilmuan bayi yang diberi susu formula memiliki IQ yang lebih rendah dibandingkan dengan bayi yang mendapat ASI secara eksklusif [7].

Adapun cara yang dapat dilakukan untuk memperbanyak Produksi ASI misalnya dengan cara mengkonsumsi sayur sayuran, buah buahan, adapun contoh sayuran yang dapat meningkatkan Produksi ASI adalah Jantung Pisang. Jantung pisang merupakan bunga yang dihasilkan oleh pohon pisang yang berjenis Musaceae yang berwarna gelap coklat keunguan, kemerahan dibagian luar dan warna putih krim susu dibagian dalam. Jantung pisang mengandung banyak vitamin yaitu 30kkl energi, 1 gr protein, 7 gr karbohidrat, $50 \mathrm{mg}$ lemak, 170 IU Vitamin A, 0,05 mg Vitamin B 1 dan $10 \mathrm{mg}$ Vitamin C. Tentu saja semua kandungan nutrisi yang ada di dalam jantung pisang sangat berguna bagi tubuh kita [8].

Jantung pisang mudah di peroleh dan pohonya mudah di taman, jenis jantung pisang yang digunakan dalam penelitian ini adalah jantung pisang kepok karena memiliki rasa yang lebih gurih dan dapat diolah dengan berbagai macam ragam olahan makanan sehingga mudah dikonsumsi ibu menyusui untuk meningkatkan produksi ASI minimal selama 6 bulan pertama dan membuat ASI ibu semakin lancar serta membantu kesuksesan pemberian ASI secara eksklusif sehingga membantu bayi untuk dapat tumbuh dan berkembang dengan baik sesuai yang diharapkan oleh orang tua[9].

\section{Metode}

Jenis penelitian yang digunakan adalah penelitian kuantitatif, dengan menggunakan studi desain Quasi Experiment dengan desain Pretest-Posttest With Control Group yaitu dengan melakukan pretest pada keduakelompok dan diikuti intervensi pada kelompok eksperiman[10].Penelitian ini dilaksanakan di Desa Sidodadi Ramunia Kecamatan Beringin Kabupaten Deli Serdang pada bulan Mei-Juni 2020. Populasi dalam penelitian ini adalah seluruh ibu menyusui bayi usia 0-6 bulan. Pengambilan sampel dengan menggunakantehnik Probability 
Sampling yaitu Simple Randomsampling dengan menentukan kriteria inklusi dan eksklusi sebanyak 20 orang ibu menyusui yang di bagi menjadi dua kelompok yaitu 10 orang untuk kelompok eksperiman dan 10 orang untuk kelompok Kontrol [11].

Pemberian rebusan jantung pisang pada kelompok intervensi diberikan 2 kali sehari pagi dan sore, sekali pemberian sebanyak $200 \mathrm{cc}$ selama 7 hari sedangkan pada kelompok kontrol hanya dilakukan observasi tidak diberikan rebusan jantung pisang. Instruman yang digunakan dalam penelitian ini adalah lembar observasi dan kuisioner yang dibuat secara terstruktur berdasarkan teori yang telah dipelajari terkait dengan indikator produksi ASI yang ditinjau dari bayi dan gelas ukur (cc).Analisis data yang digunakan dalam penelitian ini adalah untuk data univariate sebelum dan sesudah dengan mengunakan data distribusi frekuensi dan Analisa data Bivariat dengan menggunakan Independent Sample Test untuk mengetahui pengaruh Jantung Pisang terhadap produksi ASI dengan tingkat kepercayaan 95\% [12].

Etika Penelitian, Peneliti ini sudah lolos kaji etik (mendapat persetujuan etik) dan mendapatkan sertifikat etik dari Komisi Etik Penelitian KesehatanFakultas Keperawatan Universitas Sumatera Utara pada tanggal 23 Maret 2020 dengan nomor Reg.No : 2083/III/SP/2020.

\section{Hasil dan Diskusi}

a. Data Univariat

Tabel 1. Distribusi Frekuensi Produksi ASI berdasarkan kelancaran ASI dan Penilaian Indikator Bayi (Frekuensi BAK, Frekuensi BAB dan Jumlah Jam Tidur) pada Kelompok Intervensi Sebelum dan Sesudah Diberikan Rebusan Jantung Pisang pada Ibu Menyusui.

\begin{tabular}{|c|c|c|c|c|}
\hline \multirow{2}{*}{ Varibael } & \multicolumn{2}{|c|}{ Sebelum } & \multicolumn{2}{|c|}{ Sesudah } \\
\hline & $\mathbf{f}$ & $\%$ & $\mathbf{f}$ & $\%$ \\
\hline \multicolumn{5}{|l|}{ Kelancaran ASI } \\
\hline Tidak Lancar & 7 & 70.0 & 4 & 40.0 \\
\hline Lancar & 3 & 30.0 & 6 & 60.0 \\
\hline Total & 10 & 100.0 & 10 & 100.0 \\
\hline \multicolumn{5}{|l|}{ Frekuensi BAK } \\
\hline$<6$ kali sehari & 7 & 70.0 & 1 & 10.0 \\
\hline $6-8$ kali sehari & 3 & 30.0 & 9 & 90.0 \\
\hline Total & 10 & 100.0 & 10 & 100.0 \\
\hline \multicolumn{5}{|l|}{ Frekuensi BAB } \\
\hline$<2-5$ kali sehari & 3 & 30.0 & 2 & 20.0 \\
\hline $2-5$ kali sehari & 7 & 70.0 & 8 & 80.0 \\
\hline Total & 10 & 100.0 & 10 & 100.0 \\
\hline \multicolumn{5}{|c|}{ Jumlah Jam Tidur Bayi } \\
\hline$<16-18$ jam per/hari & 7 & 70.0 & 2 & 20.0 \\
\hline $16-18 \mathrm{jam}$ per/hari & 3 & 30.01 & 8 & 80.0 \\
\hline Total & $\mathbf{1 0}$ & 100.0 & 10 & 100.0 \\
\hline
\end{tabular}

Berdasarkan tabel 1 diketahui pada kelompok intervensi sebelum pemberian rebusan jantung pisang di lihat dari kelancaran ASI mayoritas ibu mengalami ASI tidak lancar sebanyak 7 responden $(70 \%)$ dan sesudah pemberian rebusan jantung pisang mayoritas ASI ibu menjadi lancar sebanyak 6 responden (60\%), sedangkan frekuensi BAK bayi sebelum pemberian rebusan jantung pisang mayoritas BAK kurang dari 6 kali sehari sebanyak 7 responden (70\%) dan sudah pemberian rebusan jantung mayoritas BAK 6-8 kali sehari sebanyak 9 responden (90\%), frekuensi $\mathrm{BAB}$ sebelum dan sesudah pemberian jantung pisang mayoritas 2-5 kali sehari sebanyak 7 responden (70\%) dan 8 responden (80\%) dan jumlah tidur bayi sebelum pemberian rebusan jantung pisang mayoritas < 16-18 jam per/hari sebanyak 7 responden (70\%) dan setelah pemberian rebusan jantung pisang mayoritas tidur bayi 16-18 jam per/hari sebanyak 8 rsponden (80\%). 
Tabel 2.Distribusi Frekuensi Produksi ASI berdasarkan kelancaran ASI dan Penilaian Indikator Bayi (Frekuensi BAK, Frekuensi BAB dan Jumlah Jam Tidur) pada Kelompok Kontrol Sebelum dan Sesudah di Observasi pada Ibu Menyusui.

\begin{tabular}{|c|c|c|c|c|}
\hline \multirow{2}{*}{ Varibael } & \multicolumn{2}{|c|}{ Sebelum } & \multicolumn{2}{|c|}{ Sesudah } \\
\hline & f & $\%$ & $\mathbf{f}$ & $\%$ \\
\hline \multicolumn{5}{|l|}{ Kelancaran ASI } \\
\hline Tidak Lancar & 8 & 80.0 & 6 & 60.0 \\
\hline Lancar & 2 & 20.0 & 4 & 40.0 \\
\hline Total & 10 & 100.0 & 10 & 100.0 \\
\hline \multicolumn{5}{|l|}{ Frekuensi BAK } \\
\hline$<6$ kali sehari & 8 & 80.0 & 6 & 60.0 \\
\hline $6-8$ kali sehari & 2 & 20.0 & 5 & 50.0 \\
\hline Total & 10 & 100.0 & 10 & 100.0 \\
\hline \multicolumn{5}{|l|}{ Frekuensi BAB } \\
\hline$<2-5$ kali sehari & 6 & 60.0 & 6 & 60.0 \\
\hline $2-5$ kali sehari & 4 & 40.0 & 4 & 40.0 \\
\hline Total & 10 & 100.0 & 10 & 100.0 \\
\hline \multicolumn{5}{|c|}{ Jumlah Jam Tidur Bayi } \\
\hline$<16-18$ jam perhari & 9 & 90.0 & 7 & 70.0 \\
\hline $16-18$ jam perhari & 1 & 10.0 & 3 & 30.0 \\
\hline Total & $\mathbf{1 0}$ & 100.0 & 10 & 100.0 \\
\hline
\end{tabular}

Berdasarkan tabel 2 diketahui pada kelompok kontrol sebelum dilakukan observasi mayoritas ASI tidak lancar sebanyak 8 responden (80\%) dan setelah dilakukan observasi mayoritas tetap meproduksi ASI yang tidak lancar sebanyak 6 responden (60\%), sedangakan frekuensi BAK bayi sebelum dan sesudah dilakukan observasi mayoritas $<6$ kali sehari yaitu sebanyak 8 responden (80\%) dan 6 responden (60\%), sedangkan frekuensi BAB bayi sebelum dan sesudah observasi mayoritas bayi $\mathrm{BAB}<2-5$ kali sehari yaitu masing-masing 6 responden $(60 \%)$ dan jumlah tidur bayi sebelum dan sesudah dilakukan observasi mayoritas bayi tidur $<16-18$ jam per/hari yaitu 9 responden (90\%) dan 7 responden (70\%).

\section{b. Data Bivariat}

Tabel 3. Hasil Uji Independent Sample Test pada Kelompok Intervensi dan Kelompok Kontrol

\begin{tabular}{|c|c|c|c|c|c|c|}
\hline Variabel & & n & Mean & SD & Beda Mean & p value \\
\hline \multirow{2}{*}{ Kelancaran ASI } & Intervensi & 10 & 459.0 & 123.058 & \multirow{2}{*}{149.0} & \multirow[t]{2}{*}{0.01} \\
\hline & Kontrol & 10 & 310.0 & 133.083 & & \\
\hline \multirow{2}{*}{ Frekuensi BAK } & Intervensi & 10 & 7.40 & 1.430 & \multirow[b]{2}{*}{2.400} & \multirow{2}{*}{0.001} \\
\hline & Kontrol & 10 & 5.00 & 1.333 & & \\
\hline \multirow{2}{*}{ Frekuensi BAB } & Intervensi & 10 & 2.80 & 0.919 & \multirow{2}{*}{0.900} & \multirow{2}{*}{0.027} \\
\hline & Kontrol & 10 & 1.90 & 0.738 & & \\
\hline \multirow{2}{*}{$\begin{array}{l}\text { Jumlah Jam Tidur } \\
\text { Bayi }\end{array}$} & Intervensi & 10 & 14.60 & 3.239 & \multirow{2}{*}{3.100} & \multirow{2}{*}{0.025} \\
\hline & Kontrol & 10 & 11.50 & 2.369 & & \\
\hline
\end{tabular}

Berdasarkan tabel 3 diketahui bahwa dari hasil Uji Independent Sample Test pada kelompok intervensi dan kelompok kontrol terdapat berbedaan rata-rata kelancaran ASI sebesar 149.0 dengan nilai $\mathrm{p}$ value 0.01 yang artinya ada perbedaan yang significant pada kedua kelompok tersebut, dan berdasarkan frekuensi BAK Bayi nilai perbedaan rata-rata pada kelompok intervensi dan kelompok kontrol 2.400 dengan nilai $\mathrm{p}$ value 0.001 hal ini juga menunjukkan berbedaan yang significant, dan ditinjau dari frekuensi $\mathrm{BAB}$ bayi perbedaan nilai rata-rata pada kelompok intervensi dan kelompok kontrol 0.900 dengan nilai p value 0.027 hal ini juga menunjukkan ada perbedaan yang significant dan di lihat dari jumlah jam tidur bayi di peroleh beda nilai rata-rata pada kelompok intervensi dan kelompok kontrol sebesar 3.100 dengan nilai p value 0.025 . Hal ini menunjukkan bahwa ada pengaruh rebusan jantung pisang terhadap produksi ASI yang di lihat dari kelnacaran ASI dan indikator bayi. 


\section{Pembahasan}

\section{a. Kelancaran ASI}

Produksi ASI merupakan hasil stimulasi hormon prolaktin yang diproduksi oleh kelenjar hipofisis anterior. Jika bayi mengisap puting susu ibu maka ASI akan dikeluarkan dari sinus laktiferus dan mengalir ke tubuh bayi [13]. Pada penelitian ini pemberian rebusan jantung pisang pada kelompok intervensi diberikan 2 kali sehari pagi dan sore, sekali pemberian sebanyak $200 \mathrm{cc}$ selama 7 hari berturut-turut sedangkan pada kelompok kontrol hanya dilakukan observasi tidak diberikan rebusan jantung pisang.

Dari hasil penelitian diketahui kelancaran pengeluaran ASI sebelum dan sesudah diberikan rebusan jantung pisang pada kelompok intervensi sebesar 70\% responden yang ASInya tidak lancar dan hanya 30\% yang ASInya lancar sedangkan setelah diberi rebusan jantung pisang terdapat $60 \%$ yang lancar dan yang tidak lancar 40\%, pada kelompok kontrol kelancaran ASI sebelum observasi $80 \%$ yang tidak lancar dan setelah observasi masih $60 \%$ yang tidak lancar, pada kelompok kontrol tidak terjadi penurunan yang significant dan berdasarkan hasil uji Independent Sample Test pada kelompok intervensi dan kelompok kontrol terdapat perbedaan nilai rata-rata sebesar 149.0 dengan nilai $\mathrm{p}$ value 0.01 hal ini menunjukkan bahwa ada pengaruh rebusan jantung pisang terhadap produksi ASI di lihat dari kelancaran ASI ibu.

Hal ini sejalan dengan penelitianApriza (2016) diperoleh hasil penelitian rerata ekskresi ASI sebelum diberikan rebusan jantung pisang 385 cc dengan standar deviasi 82,876 dan sesudah diberi rebusan jantung pisang $720 \mathrm{cc}$ dengan standar deviasi 86,450 dengan nilai p0,001 dari hasil penelitianya disimpulkan bahwa ada pengaruh konsumsi rebusan jantung pisang terhadap ekskresi ASI pada ibu menyusui di Desa Kuapan wilayah kerja Puskesmas Tambang [14]. Penelitian ini juga sama dengan penelitian sebelumnya bahwa jantung pisang dan daun katuk efektif digunakan untukmeningkatkan produksi ASI pada ibu menyusui, dari hasil penelitianya terhadap 28 responden diperoleh $p$ value, 0.040yang artinya ada pengaruh konsumsi jantung pisang dan daun katuk terhadap peningkatan produksi ASI pada ibu menyusui[15].

Jantung pisang merupakan tanaman pisang yang dimanfaatkan untuk meningkatkan produksi ASI. Dipilihnya jantung pisang karena harganya tidak terlalu mahal dan mudah diperoleh bahkan bisa ditanam sendiri diperkarangan rumah, selain itu jantung pisang mengandung laktogogum zat gizi yang dapat melancarkan produksi ASI. Banyak jenis pada jantung pisang tetapi Pada penelitian ini jantung pisang yang dipilih adalah jenis jantung pisang kepok, karena memiliki rasa yang gurih dan memiliki kandungan tannin yang sedikit sehingga tidak terasa pahit. Selain itu jantung pisang kepok memiliki kandungan nutrisi yang lengkap seperti vitamin A, Vitamin B1, Vitamin C, Lemak, Protein, Karbohidrat, Kalsium, energi (kkal) dan air [16]. Menurut asumni peneliti pada kelompok intervensi terjadi peningkatan produksi ASI pada ibu menyusui karena ibu mengkonsumsi rebusan jantung pisang kepok dengan teratur selama 7 hari berturut-turut sedangkan pada kelompok kontrol tidak terjadi peningkatan produksi ASI karena ibu tidak diberikan rebusan jantung pisang tetapi hanya diobservasi selama 7 hari.

\section{b. Frekuensi BAK}

Berdasarkan hasil analisa lembar observasi pada 10 responden kelompok intervensi diperoleh frekuensi BAK bayi sebelum ibu diberikan rebusan jantung pisang kurang dari 6 kali sehari sebanyak 70\% dan setelah ibu diberikan rebusan jantung pisang frekuensi BAK menjadi 6-8 kali sehari sebanyak 90\%, sedangkan pada kelompok kontrol sebelum di observasi $80 \%$ dan setelah di observasi frekuensi BAK tetap kurang dari 6 kali sehari dan berdasarkan hasil analisis bivariate terhadap kelompok intervensi dan kelompok kontrol di peroleh nilai p value 0.001 yang artinya terdapat perbedaan yang significant pada kedua kelompok tersebut.

Normalnya pada bayi yang mendapat ASI cukup urinnya berwarna jernih kekuningan dan kencingnya banyak hingga mencapai 6-8 kali ganti popok atau celana dalam sehari.Hal ini sejalan dengan teori Maritalia (2014) yang megungkapkan bahwa tanda-tanda yang menunjukkan bahwa bayi kurang mendapatkan asupan ASI, salah satunya adalah urine bayi yang berwarna kekuningan pekat, baunya tajam, dan jumlahnya sedikit (kurang dari enam kali dalam sehari) [17]. Hal ini sama dengan pendapat Tri Budiarti (2017) bahwa kelancaran produksi ASI yang dilihat dari indikator 
bayi salah satunya adalah dari BAK bayi minimal 6 kali dalam 24 jam dengan warna urine kuning jernih [18].

Makanan bergizi yang dikonsumsi ibu selama menyusui bayinya akan dimetabolisme oleh sistem pencernaan.Zat-zat gizi akan diserap oleh tubuh ibu dan dialirkan ke dalam ASI sehingga ASI menjadi lebih banyak diproduksi dan di konsumsi oleh bayinya, apabila bayi tercukupi ASInya maka frekuensi BAKnya akan semakin baik dan normal jumlah frekuensi BAKny, dari hasil penelitian yang diperoleh frekuensi BAK bayi dalam batas normal yaitu $6-8$ kali sehari, hal ini dikarenakan ibu mengkonsumsi rebusan jantung pisang yang memiliki zat gizi yang banyak sehingga asupan gizi ibu terpenuhi. Hal ini juga sejalan dengan penelitian yang dilakukan oleh dari hasil penelitianya ada perbedaan produksi ASI antara sebelum dan sesudah mengkonsumsi minuman jantung pisang pada ibu nifas menyusui di Desa Gertenga wilayah kerja UPT Puskesmas Karang penang Sampang.

\section{c. Frekuensi BAB}

Berdasarkan hasil penelitian diperoleh pada kelompok intervensi dan kelompok kontrol frekuensi BAB bayi mayoritas pada rentang 2-5 kali sehari dan berdasarkan hasil uji Independent Sample Test pada kedua kelompok tersebut diperoleh nilai $\mathrm{p}$ value 0.027 yang artinya ada pengaruh pemberian jantung pisang terhadap produksi ASI di lihat dari indikator frekuensi BAB bayi. Hal ini sejalan dengan penelitian sebelumnya tentang penerapan pemberian olahan jantung pisang untuk kelancaran produksi ASI, dari hasil penelitian yang dilihat dari indikator bayi, ibu yang diberikan olahan jantung pisang BAB bayinya 2-5 kali perhari warna kuning keemasan, frekuensi menyusui dalam sehari 8-12 kali dan adanya kenaikan berat badan bayi.

Makanan yang dikonsumsi oleh ibu yang sedang dalam masa menyusui tidak secara langsung mempengaruhi masa ataupunjumlah air susu yang dihasilkan,didalam tubuh terdapat cadangan makanan ataupun zat gizi yang bisa digunakan bila sewaktu-waktu diperlukan. Akan tetapi jika makanan yang di konsumsi ibu terus menerus tidak mengandung cukup gizi yang diperlukan maka kelenjar yang memproduksi ASI tidak akan dapat bekerja atau berfungsi dengan baik dan pada akhirnya akan berpengaruh terhadap kualitas produksi ASI dan gizi bayi serta pencernaan bayi karena bayi belum mempunyai enzim dan protein yang lengkap sampai bayi usia 6 bulan [19].

Bayi usia 0 sampai 6 bulan memiliki usus yang belum sempurna, jadi protein dan bakteri pathogen akan lebih mudah masuk ke tubuh bayi. Kandungan antibodi yang ada pada ASI dapat melindungi sistem pencernaan bayi dan dapat membuat kekebalan pasif, mengurangi terjadinya penyakit infeksi atau alergi sebelum usus bayi dapat berfungsi dengan sempurna sehingga ASI sangat diperlukan untuk pencernaan bayi agar bayi dapat BAB dengan normal. Bayi yang cukup ASI pola BABnya $2-5$ kali perhari, BAB yang dihasilkan tidak terlalu encer, berwarna kuning keemasan, tidak pekat, sedangkan bayi yang menkonsusmsi susu formula pola BABnya hanya 1 kali dalam sehari dan BABnya berwarna putih pucat[20].

\section{d. Jumlah Jam Tidur}

Tidur merupakan salah satu bentuk adaptasi fisiologi bayi terhadap lingkungan sekitarnya, tidur juga merupakan bagian dari prioritas utama bagi bayi, karena pada saat bayi sedang tidurlah terjadi repair neuro-brain dan kurang lebih 75\% hormon pertumbuhan diproduksi oleh tubuh bayi (Nughraheni \& Ambarwati (2018). Kualitas dan kuantitas tidur bayi sangat perlu untuk tetap dijaga agar bayi tetap sehat. Dari hasil penelitian diperoleh jumlah jam tidur bayi pada kelompok intervensi sebelum ibu diberikan rebusan jantung pisang $70 \%$ bayi tidur kurang dari $16-18$ jam perhari dan setelah ibu mengkonsumsi rebusan jantung pisang jam tidur bayi $80 \%$ mencapai 16 18 jam perhari, sedangkan pada kelompok kontrol sebelum produksi ASI ibu di observasi jam tidur bayi $90 \%$ kurang dari 16 - 18 jam perhari dan setelah produksi ASI ibu di observasi jam tidur bayi menjadi $70 \%$. Berdasarkan hasil uji bivariate rata-rata berbedaan jam tidur bayi pada kelompok intervensi dan kelompok kontrol sebesar 3.100 dengan nilai $\mathrm{p}$ value 0.025 yang artinya terdapat perbedaan yang significant terhadap kedua kelompok tersebut jika di lihat dari indikator jam tidur bayi.

Hasil ini sejalan dengan penelitian Handayani. R (2020) bahwa dari 173 responden terdapat $61,8 \%$ bayi yang mendapatkan ASI secara Eksklusif dan $86,1 \%$ bayi dengan kualitas tidur 
adekuat. Hasil dari analisis statistik menggunakan uji Chi Square diperoleh nilai p value $0,000<$ 0,05 yang artinya ada hubungan antara pemberian ASI dan kualitas tidur pada bayi usia 0-6 bulan di Wilayah Kerja Puskesmas Maesan Bondowoso. Penelitian ini direkomendasikan kepada ibu menyusui agar menjaga kualitas tidur pada bayi untuk mendukung pertumbuhan dan perkembangan bayi secara optimal dengan cara pemberian ASI [21].

Nutrisi dalam ASI mencakup hampir 2003 unsur zat makanan. Hubertin (2007) menyatakan bahwa ASI juga mengandung banyak protein, salah satunya adalah triptofan (asam amino) yang dapat mempermudah proses tidur pada bayi. Bayi juga akan lebih mudah tertidur dan dalam kondisi tenang jika asupan ASI sesuai dengan kebutuhannya yang diberikan secara eksklusif.Kualitas dan jumlah jam tidur bayi sangat berpengaruh pada pertumbuhan dan perkembangan bayi, bayi yangjam tidurnya cukup akan mengalami regenerasi sel-sel tubuh dan perkembangan otaknya, oleh karena itu kualitas dan jam tidur bayi harus dijaga. Bayi yang tidur cukup tanpa sering terbangun, lebih bugar dan tidak rewel pada keesokan harinya. Tidur memiliki peranan yang sangat penting dalam kesehatan emosi, fisik, mental dan system imunitas tubuh, karena pentingnya kebutuhan jam tidur pada bayi maka kebutuhan tidur harus terpenuhi supaya tidak berpengaruh pada perkembangan tubuhnya[22].

Berdasarkan hasil penelitian Mutyah Diyan (2017) diperoleh bahwa30\% bayi tidur dengan baik hingga 13-14 jam atau sekitar 50-60\% perharinya dan 70\% bayi sering terbangun dari tidurnya lebih dari 3 kali dengan lama waktu sekitar satu jam. Bayi yang jam tidurnyabelum cukup keesokan harinya akanlebih sering menangis dan rewel [23]. Menurut asumsi peneliti dari hasil penelitian pada kelompok intervensi jam tidur bayi sesudah ibu diberi rebusan jantung pisang rata -rata bayi tidur 16 - 18 jam perhari atau mencapai $80 \%$ jam tidurnya hal ini dikarenakan kebutuhan nutrisi ibu dapat terpenuhi dengan baik sehingga bayi cukup menkonsumsi ASI dan dapat tidur dengan baik sesuai dengan kebutuhan bayi.

\section{Kesimpulan}

Berdasarkan hasil penelitian yang telah dilakukan, diperoleh kelancaran ASI pada kelompok intervensi dan kelompok kontrol terdapat perbedaan nilai sebesar 149.0 dengan nilai $p$ value 0.01 yang artinya terdapat perbedaan yang significant pada kedua kelompok tersebut dan dilihat dari indicator bayi perbedaan nilai rata-rata frekuensi BAK bayi pada kelompok intervensi dan kontrol 24.00 dengan pvalue 0.001 , perbedaan nilai rata-rata frekuensi BAB bayi 0.900 dengan nilai pvalue 0.027 dan dilihat dari Jam tidur bayi terdapat perbedaan nilai 3.100 dengan nilai pvalue 0.025 yang artinya ada pengaruh pemberian rebusan jantung pisang terhadap produksi ASI pada Ibu menyusui bayi 0-6 bulan baik dilihat dari kelancaran ASI ibu ataupun dari indicator bayi.Disarankan kepada ibu menyusui agar dapat rutin mengkonsumsi rebusan jantung pisang karena jantung pisang terbukti dapat menambah produksi ASI.

\section{Ucapan Terima Kasih}

Terima kasih kepada Kementerian Pendidikan dan Kebudayaan (KEMENDIKBUD) dan kepada Lembaga Layanan Pendidikan Tinggi Wilayah I (LLDIKTI) serta Desa Ramunia Kecamatan Beringin Kabupaten Deli Serdang. Dengan adanya bantuan dari semua pihak, penelitian ini dapat berlangsung dengan baik semoga hasil penelitian ini dapat bermanfaat untuk masyarakat khususnya ibu menyusui

\section{Referensi}

[1] P. Hastuti and I. T. Wijayanti, "Analisis Deskriptif Faktor yang Mempengaruhi Pengeluaran Asi pada Ibu Nifas di Desa Sumber Kecamatan Sumber Kabupaten Rembang,” 6th Univ. Res. Colloq. 2017 Univ. Muhammadiyah Magelang, vol. 1, pp. 223-232, 2017.

[2] Y. D. F. H. I. Riona Sanjaya, "Faktor-Faktor Yang Berhubungan Dengan Pemberian ASI Eksklusif," J. Matern. UAP (JAMAN UAP) Univ. Aisyah Pringsewu, vol. 1, no. 2, pp. 15-25, 2020.

[3] Ayu Devita Citra Dewi, "Faktor-Faktor yang Mempengaruhi Kelancaran Produksi ASI," J. 'Aisyiyah Med., vol. 4, no. 1, pp. 22-34, 2019. 
[4] N. Yulita, S. Juwita, and A. Febriani, "Postpartum Mother's Behavior in Increasing ASI Production," J. Ilm. Kebidanan, vol. 7, no. 1, pp. 53-61, 2020.

[5] Roesli, U. (2012). Inisiasi Menyusu Dini Plus Asi Eksklusif. Jakarta: Pustaka Bunda, 2012.

[6] E. Husanah, "Asuhan Kebidanan Pada Ny P Dengan Masalah Produksi ASI Melalui Terapi Kurma," J. Komun. Kesehat., vol. XI, no. 1, 2020.

[7] A. D. C. Dewi, "Faktor-Faktor yang Mempengaruhi Kelancaran ASI," J. 'Aisyiyah Med., vol. 4, no. 1, pp. 22-34, 2019.

[8] M. A.-G. and D. K. W. Mery Napitupulu, "Adsorption Of Cd ( II ) By Carbon Prepared From Peels And Stems," Cellul. Chem. Technol, vol. 53, no. I, pp. 387-394, 2019.

[9] D Maritalia, Asuhan kebidanan nifas dan menyusui. Yogyakarta: Pustaka Pelajar, 2014.

[10] Nevel Mangelep, “Metode Penelitian Eksperimen.” 2012.

[11] S. Notoatmodjo, Metodologi Penelitian Kesehatan. Jakarta: Rineka Cipta, 2016.

[12] Sugiyono, Metodologi Penelitian Pendidikan. Bandung: alf, 2015.

[13] W. D. Lassek and S. J. C. Gaulin, "Maternal milk DHA content predicts cognitive performance in a sample of 28 nations," JohnWiley Sons Ltd Matern. Child Nutr., vol. 11, pp. 773-779, 2015.

[14] Apriza, "Pengaruh Konsumsi Rebusan Jantung Pisang Terhadap Ekskresi ASI pada Ibu Menyusui di Desa Kuapan Wilayah Kerja Puskesmas Tambang," J. Ners Univ. Pahlawan Tuanku Tambusai, vol. 1, no. 1, 2017.

[15] H. Astuti, "Efektifitas Jantung Pisang Dan Daun Katuk Terhadap Produksi Asi Pada Ibu Menyusui Di Desa Teluk Kiambang Wilayah Kerja Puskesmas Tempuling Kecamatan Tempuling Kabupaten Indragiri Hilir," J. Selodang Mayang, vol. 6, no. 1, pp. 15-22, 2020.

[16] F. Mosca and M. L. Giannì, "Human milk: composition and health benefits," La Pediatr. Medica e Chir. - Med. Surg. Pediatr., vol. 39, pp. 47-52, 2017.

[17] D. Maritalia,Asuhan kebidanan nifas dan menyusui. Yogyakarta: Pustaka Pelajar.

[18] T. B. Frisca Dewi Yunadi, "Ages Of Age And Nutrition Status With Design Dehydration Degree Of Diarrhea In Under Fives," J. Kesehat. Al irsyad, vol. X, no. 2, pp. 20-27, 2017.

[19] P. Prentice et al., "Breast milk nutrient content and infancy growth," Padiatrica Publ. by John Wiley Sons Ltd behalf Found. Acta Padiatrica, pp. 641-647, 2016.

[20] R. J. Mcinnes, A. Arbuckle, and P. Hoddinott, "How UK internet websites portray breast milk expression and breast pumps : a qualitative study of content," McInnes al. BMC Pregnancy Childbirth, pp. 1-11, 2015.

[21] R. Handayani, "Hubungan pemberian asi dengan kualitas tidur pada bayi usia 0-6 bulan di wilayah kerja puskesmas maesan bondowoso," http://repository.unmuhjember.ac.id/, 2020.

[22] R. K. Dasar, P. Diare, and M. Provinsi, Konsep Penerapan ASI Eksklusif. Jakarta: EGC, 2007.

[23] D. Diyan Mutyah and A. E, "Pengaruh Pemberian Pijat Bayi terhadap Kualitas dan Kuantitas Tidur pada Bayi Usia 6-12 Bulan di Masyarakat Pesisir Surabaya," in Prosiding HEFA 1st 2017 Publikasi Riset Kesehatan untuk Daya Saing Bangsa, 2017, p. 171. 